\title{
AS REPRESENTAÇÕES DO FEMININO E DO MASCULINO NA CONTEMPORANEIDADE: UM ESTUDO SOBRE AS NOVAS CONFIGURAÇÕES FAMILIARES
}

\author{
Beatriz Almeida Gabardo*, Regina Célia Ciriano Calil.
}

\section{Resumo}

Esta pesquisa teve como objetivo discutir a representação do feminino e do masculino e as mudanças observadas nas funções materna e paterna na liquidez do contemporâneo. Foi realizado um estudo teórico crítico com levantamento de artigos científicos dos cinco últimos anos com temas relacionados às relações edípicas que permeiam a família moderna e pós-moderna. Nesta pesquisa qualitativa o método utilizado para sistematização de dados foi a Análise Temática proposta por Bardin. Os artigos foram levantados em três bases de dados indexadas por meio das palavraschaves: complexo de Édipo; função materna e função paterna. Foram selecionados 24 artigos e estes compuseram a análise deste trabalho. A partir da análise temática, conclui-se que as funções materna e paterna podem sem entendidas como operadores lógicos desvinculando-se da anatomia do sujeito que exercerá tal função e voltando-se para necessidade de que haja um outro que a opere. A diferença anatômica é importante na constituição psíquica do sujeito não podendo ser totalmente ignorada. O complexo de Édipo é um dos conceitos centrais e fundamentais da Psicanálise, mas também deve ser visto a partir de suas características normalizadoras e normativas da sexualidade humana.

Palavras-chave: Função materna, função paterna, complexo de Édipo.

\section{Introdução}

O tema desta pesquisa aparece com certa frequência quando se fala de Psicanálise. É comum o questionamento de conceitos fundamentais, como o complexo de Édipo, frente às características do século $\mathrm{XXI}$. Sendo assim, as diferentes configurações familiares são alvos constantes de preconceitos e de questionamentos em relação a sua efetividade, capacidade e importância na formação da subjetividade dos sujeitos que as compõem ${ }^{1,2}$.

O estudo e a discussão sobre esse tema tem grande importância, pois pretende repensar a teoria à luz do momento atual com o sujeito contemporâneo e ainda guiar para maior compreensão das diferentes configurações familiares, de sua legitimação e de suas influências na formação da subjetividade e no desenvolvimento da saúde mental ${ }^{1}$.

Esta pesquisa tem por objetivo discutir, por meio de estudo teórico crítico, a representação do feminino e do masculino nas novas configurações familiares na contemporaneidade e como isso impacta as respectivas funções materna e paterna. Além de refletir sobre o complexo de Édipo dentro do núcleo familiar atual e suas repercussões na formação da subjetividade e na saúde mental dos indivíduos.

\section{Resultados e Discussão}

O levantamento bibliográfico foi feito por meio de três palavras-chaves: complexo de Édipo, função materna e função paterna, nas bases The Scientific Electronic Library Online - SciELO, Periódicos Eletrônicos em Psicologia - PePSIC e no Portal de Periódicos CAPES - MEC. Foram selecionados textos dos últimos cinco anos dentro da abordagem psicanalítica e das temáticas definidas nos objetivos desta pesquisa.

O número total de artigos selecionados para esta pesquisa foi 24 unidades. Destes, 12 artigos apresentaram discussões que faziam um apanhado das teorias analíticas clássicas, articulando conceitos com casos e/ou levantamentos bibliográficos.
Os outros 12 artigos apresentaram articulações das representações do feminino e/ou masculino com a contemporaneidade, assim como a compreensão do complexo de Édipo nas novas configurações familiares em uma releitura desses conceitos clássicos a luz da atualidade.

A partir da análise temática ${ }^{3}$, conclui-se que as funções materna e paterna podem ser entendidas como operadores lógicos na estruturação do inconsciente, desvinculando-se da materialidade anatômica genital do sujeito que exercerá tal função e voltando-se para necessidade de que haja um outro que a opere. A diferença anatômica aparece como um real do corpo na constituição psíquica do sujeito não podendo ser totalmente desvinculada das questões edipianas e do contato com a feminilidade e a masculinidade. O complexo de Édipo é um dos conceitos centrais e fundamentais da Psicanálise, mas também deve ser visto a partir de suas características normalizadoras e normativas da sexualidade humana.

\section{Conclusões}

Mais estudos críticos se fazem necessários para reavaliação dos conceitos, práticas e discursos psicanalíticos frente aos tempos atuais e suas novas configurações. A psicanálise é convocada a acompanhar o original presente nos tempos atuais de pluralidade a partir da uma leitura atualizada e crítica de seus conceitos teóricos fundamentais.

\section{Agradecimentos}

Agradeço a UNIP que fomentou esta pesquisa assim como a querida Profa. Dra. Regina Célia Ciriano Calil que me orientou nesta pesquisa com tanto carinho e dedicação.

1 PERELSON, S. A parentalidade homossexual: uma exposição do debate psicanalítico no cenário francês atual. Estudos Feministas, v. 14, n. 3, p. 709730 Set-Dez, 2006

2 ROUDINESCO, E. A família em desordem. Rio de Janeiro: Jorge Zahar, 2003 .

${ }^{3}$ BARDIN. L. Análise de Conteúdo. Lisboa: Edições 70, 1977. 